\title{
SOME ASPECTS OF BREAST-FEEDING IN BELFAST
}

\author{
BY \\ W. A. B. CAMPBELL and E. A. CHEESEMAN \\ From the Royal Maternity Hospital, Belfast, and the Department of Social and Preventive Medicine in the \\ Queen's University of Belfast
}

\section{PURPOSE OF THE INQUIRY}

The object of this survey was the comparison of the "incidence" of breast feeding among mothers confined at the Royal Maternity Hospital, Belfast, with that among mothers confined elsewhere in the city. The data were collected in such a way that this comparison was possible at various ages of the infant up to a maximum of 6 months. Information was collected about factors likely to influence breast feeding so that, where necessary, allowance could be made for them.

The inquiry was not concerned with the advantages or disadvantages of breast feeding and no attempt has been made to compare breast-fed with artificiallyfed children. There is already a large literature on these particular aspects of infant feeding (e.g. Gairdner, 1945; Cruickshank, 1945; Stevenson, 1947; Stewart and Westropp, 1953) and, though improvements in feeding techniques and quality of artificial foods, coupled with an increased awareness of the value of adequate vitamin supplements, has tended to minimize the differences in health experienced by infants fed in different ways, it remains true that the easiest method of feeding a baby properly is on the breast, providing breast feeding is correctly and successfully established.

\section{The Data}

The inquiry was limited to mothers who had their babies between September 1 and November 30, 1951, and who were normally resident in the County Borough of Belfast. In the 3 months there were 279 live births to such mothers in the Royal Maternity Hospital. Each birth was identified on the notification of births register maintained by the Belfast Health Committee, and the next live birth on the register was selected as a member of a control group. With this method of selection it is reasonable to assume that the Control group was representative of births to Belfast mothers, exclusive of those confined in the Royal Maternity Hospital, during the 3-months period.

Each mother was visited monthly by a health visitor until her infant reached the age of 6 months or until breast feeding was stopped, whichever was the earlier. For this purpose the end of breast feeding implied that the child was not receiving breast milk at all.

Multiple births were excluded from the analysis because of the special feeding problems involved; this reduced the size of the groups by sixteen in the Royal Maternity Hospital group (R.M.H.) and by twelve in the Control group. For various reasons it was found impossible to observe 21 children in the R.M.H. group and nine in the Control group for the complete period required and these are also excluded. The reasons for the exclusions are given in Table I, and it is unlikely that the omissions will materially affect the results; only in the lack of co-operation was there any great difference between the two groups as seven of the eight mothers concerned were members of the R.M.H. group.

TABLE I

COMPOSITION OF SAMPLES

\begin{tabular}{|c|c|c|c|}
\hline \multirow{2}{*}{\multicolumn{2}{|c|}{ Description }} & \multicolumn{2}{|c|}{ Source of Subjects } \\
\hline & & $\begin{array}{l}\text { Royal } \\
\text { Maternity } \\
\text { Hospital, } \\
\text { Belfast } \\
\text { (R.M.H. } \\
\text { Group) }\end{array}$ & $\begin{array}{l}\text { Belfast C.B. } \\
\text { Birth Noti- } \\
\text { fication } \\
\text { Register } \\
\text { (Control } \\
\text { Group) }\end{array}$ \\
\hline $\begin{array}{l}\text { Infants follc } \\
\text { life } \ldots\end{array}$ & 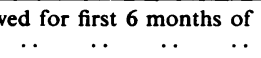 & 242 & 258 \\
\hline $\begin{array}{l}\text { Infants not } \\
\text { followed }\end{array}$ & $\left\{\begin{array}{lc}\text { Mother died } \ldots & \ldots \\
\text { Infant died } & \ldots \\
\text { Family moved } & \text { from } \\
\text { Belfast } & \ldots \\
\text { Mother would } & \text { not } \\
\text { co-operate } & \ldots\end{array}\right.$ & $\left.\begin{array}{l}1 \\
5 \\
8 \\
7\end{array}\right\}$ & $\left.\begin{array}{r}-3 \\
5 \\
1\end{array}\right\}$ \\
\hline \multicolumn{2}{|c|}{ Multiple births omitted } & 16 & 12 \\
\hline \multicolumn{2}{|c|}{$\begin{array}{l}\text { Original number of R.M.H. or Control } \\
\text { births obtained from source }\end{array}$} & 279 & 279 \\
\hline
\end{tabular}

Information obtained from birth records, or from each mother, made it possible further to subdivide each group according to the following factors:

(1) Age of mother,

(2) Sex of infant,

(3) Parity of infant,

(4) Birth weight of infant,

(5) Type of ante-natal care received. 
Moreover the Control group could be subdivided according to place of confinement.

Any defined group or sub-group of children could, from the data collected, be distributed according to three "methods" of feeding at various ages throughout the first 6 months of life. In what follows the three feeding methods are shown as:

$$
\begin{gathered}
\text { "B" } \begin{array}{c}
\text { entirely breast-fed } \\
\text { "B+" } \\
\text { breast-fed, but supplemented with artificial } \\
\text { and/or solid food }
\end{array} \\
\text { "NB" not breast-fed, i.e. fed on artificial and/or } \\
\text { solid food. }
\end{gathered}
$$

In the Tables the ages at which the distributions are shown are restricted to "Birth" ( 0 weeks), and the exact ages of $1,2,3,4,8,12,16,20$, and 24 weeks. In this context the relevant feeding recorded at "Birth" was that which constituted the major part of feeding during the first 48 hours.

\section{RESULTS}

In Table II the percentages of the 242 infants in the R.M.H. group and of the 258 infants in the Control group in each feeding category are shown. At most ages the R.M.H. and Control distributions are similar. The greatest discrepancy is likely to occur by chance more than once in twenty times, the conventional level of "significance" adopted in this report. $\dagger$

\begin{tabular}{|c|c|c|c|c|c|c|c|c|c|}
\hline \multirow{2}{*}{$\begin{array}{c}\text { Age } \\
\text { (wks) }\end{array}$} & \multicolumn{3}{|c|}{$\begin{array}{l}\text { R.M.H. Group } \\
(242 \text { infants) }\end{array}$} & \multicolumn{3}{|c|}{$\begin{array}{l}\text { Control Group } \\
\text { (258 infants) }\end{array}$} & \multicolumn{3}{|c|}{$\begin{array}{l}\text { Comparison between } \\
\text { Absolute Distributions }\end{array}$} \\
\hline & B & $\mathbf{B}+$ & NB & B & $\overline{\mathbf{B}+}$ & NB & $x^{2}$ & $n$ & $P$ \\
\hline $\begin{array}{l}0 \\
1 \\
2 \\
3 \\
4\end{array}$ & $\begin{array}{l}90 \cdot 9 \\
75 \cdot 6 \\
65 \cdot 7 \\
59 \cdot 5 \\
52 \cdot 1\end{array}$ & $\begin{array}{l}-\overline{12 \cdot 8} \\
16 \cdot 5 \\
16 \cdot 5 \\
15 \cdot 3\end{array}$ & $\begin{array}{r}9 \cdot 1 \\
11 \cdot 6 \\
17 \cdot 8 \\
24 \cdot 0 \\
32 \cdot 6\end{array}$ & $\begin{array}{l}89 \cdot 9 \\
77 \cdot 1 \\
63 \cdot 2 \\
57 \cdot 0 \\
47 \cdot 7\end{array}$ & $\begin{array}{l}\overline{10 \cdot 1} \\
15 \cdot 5 \\
12 \cdot 0 \\
15 \cdot 5\end{array}$ & $\begin{array}{l}\overline{10 \cdot 1} \\
12 \cdot 8 \\
21 \cdot 3 \\
31 \cdot 0 \\
36 \cdot 8\end{array}$ & $\begin{array}{l}0 \cdot 05 \\
1 \cdot 01 \\
1 \cdot 01 \\
4 \cdot 17 \\
1 \cdot 11\end{array}$ & $\begin{array}{l}1 \\
2 \\
2 \\
2 \\
2\end{array}$ & $\begin{array}{l}0.80-0.90 \\
0.50-0.70 \\
0.50-0.70 \\
0.10-0.20 \\
0.50-0.70\end{array}$ \\
\hline $\begin{array}{r}8 \\
12 \\
16 \\
20 \\
24\end{array}$ & $\begin{array}{r}36 \cdot 4 \\
24 \cdot 8 \\
17 \cdot 4 \\
12 \cdot 0 \\
4 \cdot 1\end{array}$ & $\begin{array}{r}10 \cdot 7 \\
11 \cdot 2 \\
10 \cdot 7 \\
9 \cdot 5 \\
14 \cdot 5\end{array}$ & $\begin{array}{l}52 \cdot 9 \\
64 \cdot 0 \\
71 \cdot 9 \\
78 \cdot 5 \\
81 \cdot 4\end{array}$ & $\begin{array}{r}30 \cdot 2 \\
21 \cdot 7 \\
17 \cdot 8 \\
12 \cdot 4 \\
7 \cdot 0\end{array}$ & $\begin{array}{l}17 \cdot 4 \\
15 \cdot 9 \\
11 \cdot 2 \\
11 \cdot 2 \\
12 \cdot 0\end{array}$ & $\begin{array}{l}52 \cdot 3 \\
62 \cdot 4 \\
70 \cdot 9 \\
76 \cdot 4 \\
81 \cdot 0\end{array}$ & $\begin{array}{l}5 \cdot 37 \\
2 \cdot 62 \\
0 \cdot 06 \\
0 \cdot 46 \\
2 \cdot 37\end{array}$ & $\begin{array}{l}2 \\
2 \\
2 \\
2 \\
2\end{array}$ & $\begin{array}{l}0.05-0.10 \\
0.20-0.30 \\
0.95-0.98 \\
0.70-0.80 \\
0.30-0.50\end{array}$ \\
\hline
\end{tabular}

\section{TABLE II}

PERCENTAGE DISTRIBUTIONS OF INFANTS IN R.M.H. AND CONTROL GROUPS, BY METHOD OF FEEDING AT VARIOUS AGES*

* In this and subsequent Tables, the distribution at 0 weeks of age gives percentage of infants in each feeding group at start of feeding. Distributions at 1, 2, etc. weeks show positions on 7th, 14th, etc. day. " $B$ " indicates breast feeding only; " $B+$ " indicates breast feeding plus bottle and/or solid feeding; "NB" indicates bottle and/or solid feeding.

It might be argued that although no apparent difference is revealed when the two groups are compared, a real difference might emerge if a

\footnotetext{
+ It should be noted that, for the comparison of percentages in any single feeding category of the order of 50 per cent., minimum differences between the R.M.H. and Control groups of about 9 per cent. would be required to indicate "significance" by this criterion, while the
smallest significant difference would be about 5 per cent. for percentages of the order of 90 or 10 per cent.
}

comparison were made of children of like parity, sex, and age of mother. It has been suggested that these factors influence breast feeding and that consequently any comparison between groups of infants should take account of these factors if they themselves differ between the compared groups. It seemed likely that the R.M.H. group would comprise a preponderance of first births to relatively young mothers in contrast to the Control group which included domiciliary births with a preponderance of second or later births to older mothers.

In fact nearly three-quarters (71 per cent.) of the R.M.H. group were first-born children compared with less than one-quarter ( 24 per' cent.) of the Control group. A comparison of the complete parity distribution between R.M.H. and Control groups reveals a highly significant difference $\left(\chi^{2}=116.45, n=7, P<0.001\right)$. The average age of the mothers of the R.M.H. group was 27.65 years, compared with 29.04 for the Control group; the distributions into six 5-year age groups differ significantly $\left(\chi^{2}=15 \cdot 53, n=5,0.01>P>0.001\right)$.

There was no material difference in the sex ratio of the R.M.H. and Control children. The sex distributions do not differ significantly, 56 per cent. of all the children were boys $\left(\chi^{2}=0.07, n=1\right.$, $0.80>P>0.70$ ).

Two other factors might influence the comparison of feeding practices between the two groups. A difference in the proportion of premature infants would have demanded a difference in amount and skill of nursing attention, and a difference in the amount and type of ante-natal instruction might have influenced the mothers differently in their attempts to establish and maintain breast feeding.

On the first point it is to be noted that of the 242 R.M.H. infants, 17 were premature by the $5 \frac{1}{2}-1 \mathrm{~b}$. weight criterion compared with nine of the 258 Control children; the difference is not significant $\left(\chi^{2}=2 \cdot 49, n=1,0.20>P>0.10\right)$ and any influence this factor might have on the present results may be ignored.

The aspect of ante-natal care, however, is not so easily dismissed. Table III (opposite) shows how the ante-natal care was obtained; any attendance which resulted in less than two visits to the responsible centre, clinic, or surgery, has been omitted in compiling this Table. Nearly all the R.M.H. mothers attended the Hospital clinic in the ante-natal period, only 21 (8.6 per cent.) did not attend at least twice. The majority of the control mothers were attended by their general practitioners during the ante-natal months, and 62.4 per cent. of them attended their own doctor to the exclusion of all other services. 
TABLE III

DISTRIBUTION OF INFANTS IN R.M.H. AND CONTROL GROUPS, BY TYPE OF ANTE-NATAL CARE RECEIVED BY MOTHERS

\begin{tabular}{|c|c|c|c|c|}
\hline \multirow{2}{*}{ Ante-Natal Care of Mother } & \multicolumn{2}{|c|}{ R.M.H. Group } & \multicolumn{2}{|c|}{ Control Group } \\
\hline & No. & Per cent. & No. & Per cent. \\
\hline 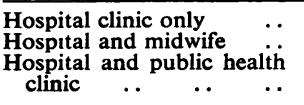 & $\begin{array}{r}205 \\
1 \\
-\end{array}$ & $\left.\begin{array}{r}84 \cdot 7 \\
0.4 \\
-\end{array}\right\} 85 \cdot 1$ & \begin{tabular}{c|}
53 \\
3
\end{tabular} & $\left.\begin{array}{c}20 \cdot 5 \\
1 \cdot 2\end{array}\right\} 21 \cdot 7$ \\
\hline $\begin{array}{l}\text { G.P. only .. } \\
\text { G.P. and hospital clinic } \ldots \\
\text { G.P. and public health clinic } \\
\text { G.P. and midwife .. }\end{array}$ & $\begin{array}{l}18 \\
15 \\
-\end{array}$ & $\left.\begin{array}{l}7 \cdot 4 \\
\frac{6 \cdot 2}{-}\end{array}\right\} 13 \cdot 6$ & \begin{tabular}{r|}
161 \\
4 \\
3 \\
8
\end{tabular} & $\left.\begin{array}{r}62 \cdot 4 \\
1 \cdot 6 \\
1 \cdot 2 \\
3 \cdot 1\end{array}\right\} 68 \cdot 2$ \\
\hline $\begin{array}{l}\text { Public health clinic only } \\
\text { None } \quad . . \\
\end{array}$ & -3 & $\left.\frac{1 \cdot 2}{-2}\right\} 1 \cdot 2$ & $\begin{array}{r}25 \\
1 \\
\end{array}$ & $\left.\begin{array}{l}9 \cdot 7 \\
0.4\end{array}\right\} 10 \cdot 1$ \\
\hline Total & $\overline{242}$ & 100 & 258 & 100 \\
\hline
\end{tabular}

From bracketed groups $\chi^{2}=201 \cdot 66, n=2, P<0 \cdot 001$

Probably the best arrangement of the data that can be made for comparing the types of ante-natal care between the R.M.H. and Control groups is that shown by the bracketed distributions in Table III; this suggests that the difference between the two groups in respect of type of ante-natal care, and therefore possibly of type of instruction about feeding, is quite considerable $\left(\chi^{2}=201 \cdot 66, n=2\right.$, $P<0.001$ ).

It would therefore appear that if parity, age of mother, and type of ante-natal care, do have an effect on the subsequent feeding habits of the children, then a legitimate comparison of the feeding methods employed by the R.M.H. and Control groups must take these factors into account. The data are not sufficiently numerous to examine properly the influence of each of these factors separately, or to permit a limitation of the comparison between the R.M.H. and the Control groups to sub-groups of children of similar parity, age of mother, and ante-natal care. After a rigorous examination of the available data the impression is left that in the R.M.H. group, after the first few weeks of life, there was a tendency for the secondor later-born children to include a greater number who were breast-fed than the first-born, and for younger mothers to breast-feed more commonly than older mothers. But neither of these tendencies is well defined or significant in the conventional sense, and in the Control group the age-of-mother influence appeared to act in the opposite direction as the children became older. It is stressed that these comments are essentially tentative and that none of the apparent differences is statistically significant; these remarks are recorded merely as points of interest which may be worthy of more detailed study with larger numbers of infants.
The possibility of such tendencies existing, coupled with the results of work done elsewhere (Hughes, 1942; Dummer, 1949; Douglas, 1950; Westropp, 1953), necessitates some form of treatment of Table II to eliminate from the comparison any possible influence of the different constitution of the R.M.H. and Control groups in respect of concomitant factors. To this end, each of the three factors was divided into two sub-groups; age of mother was split into "under 30 " and " 30 and over", parity into "first-born" and "second- and later-born", and ante-natal care into the first three categories combined of Table III and the remainder. This arrangement results in eight different combinations of sub-groups of the three factors by which a mother and child can be classified. For simplicity in subsequent discussion the combinations are described as "age-parity-care groups". The members of the R.M.H. group and Control group were distributed into these eight groups, and for each, at each tabulated age of infant, for the pooled data of 500 observations, the proportion of children in each of the feeding categories, B, B +, and NB, was estimated. These proportions were then applied to the numbers of children in the R.M.H. group at the corresponding age of infant and "age-parity-care" group, to give the number of children "expected" in each feeding category. The total expectation in each feeding group at each age of infant was found by summing the expected numbers in the eight "age-parity-care" groups. Thus for any age of infant the "expected" numbers give a distribution by feeding category based on the hypothesis that the R.M.H. children were distributed in the feeding categories in the same proportions as all children surveyed, appropriate allowance having been made for their parity, the age of their mothers and the type of ante-natal care the latter received. A similar series of calculations was then followed for the Control group.

The results of this procedure are shown in Table IV (overleaf) where the observed numbers in each feeding category are shown as percentages of the expected numbers. None of these departs widely from 100 per cent., which indicates the similarity between the observed and expected distributions. Since the latter are based on a null hypothesis it follows that the similarity between the observed results (Table II) is unlikely to be explained by the differences in parity, age of mother, and type of ante-natal care observed between the R.M.H. and Control groups. In fact the results of the process of standardization adopted suggest that the practice of feeding during the first 6 months of the child's life is even more similar in the R.M.H. and Control groups than the crude figures of Table II suggest. 
TABLE IV

DISTRIBUTION OF INFANTS IN R.M.H. AND CONTROL GROUPS BY METHOD OF FEEDING COMPARED WITH DISTRIBUTIONS EXPECTED ON THE HYPOTHESIS THAT NO DIFFERENCE EXISTS BETWEEN THE TWO GROUPS AFTER ALLOWANCE FOR DIFFERENCES IN AGE OF MOTHER, PARITY, AND TYPE OF ANTE-NATAL CARE (Observed numbers shown as percentages of expected)

\begin{tabular}{|c|c|c|c|c|c|c|c|c|c|}
\hline \multirow{2}{*}{$\begin{array}{c}\text { Age } \\
\text { (wks) }\end{array}$} & \multicolumn{3}{|c|}{ R.M.H. Group (242 infants) } & \multicolumn{3}{|c|}{ Control Group (258 infants) } & \multicolumn{3}{|c|}{$\begin{array}{l}\text { Comparison between } \\
\text { Absolute Distributions }\end{array}$} \\
\hline & B & $\mathbf{B}+$ & NB & B & $\mathbf{B}+$ & NB & $\chi^{2}$ & $n$ & $P$ \\
\hline $\begin{array}{l}0 \\
1 \\
2 \\
3 \\
4\end{array}$ & $\begin{array}{r}99 \cdot 4 \\
97 \cdot 5 \\
98 \cdot 9 \\
99 \cdot 4 \\
101 \cdot 7\end{array}$ & $\begin{array}{r}1 \overline{14} \cdot 8 \\
102 \cdot 0 \\
111 \cdot 7 \\
97 \cdot 8\end{array}$ & $\begin{array}{r}106 \cdot 2 \\
102 \cdot 9 \\
102 \cdot 5 \\
94 \cdot 7 \\
98 \cdot 4\end{array}$ & $\begin{array}{r}100 \cdot 6 \\
102 \cdot 5 \\
101 \cdot 1 \\
100 \cdot 6 \\
98 \cdot 3\end{array}$ & $\begin{array}{r}86 \cdot 7 \\
98 \cdot 1 \\
88 \cdot 1 \\
102 \cdot 1\end{array}$ & $\begin{array}{r}95 \cdot 3 \\
97 \cdot 7 \\
98 \cdot 1 \\
104 \cdot 2 \\
101 \cdot 3\end{array}$ & $\begin{array}{l}0 \cdot 16 \\
1 \cdot 40 \\
0 \cdot 12 \\
1 \cdot 31 \\
0 \cdot 14\end{array}$ & $\begin{array}{l}1 \\
2 \\
2 \\
2 \\
2\end{array}$ & $\begin{array}{l}0.50-0.70 \\
0.30-0.50 \\
0.90-0.95 \\
0.50-0.70 \\
0.90-0.95\end{array}$ \\
\hline $\begin{array}{r}8 \\
12 \\
16 \\
20 \\
24\end{array}$ & $\begin{array}{r}105 \cdot 5 \\
102 \cdot 2 \\
98 \cdot 4 \\
104 \cdot 1 \\
79 \cdot 6\end{array}$ & $\begin{array}{r}83 \cdot 2 \\
94 \cdot 0 \\
100 \cdot 4 \\
90 \cdot 6 \\
99 \cdot 9\end{array}$ & $\begin{array}{l}100 \cdot 5 \\
100 \cdot 3 \\
100 \cdot 3 \\
100 \cdot 7 \\
101 \cdot 4\end{array}$ & $\begin{array}{r}94 \cdot 4 \\
97 \cdot 7 \\
101 \cdot 5 \\
96 \cdot 6 \\
116 \cdot 6\end{array}$ & $\begin{array}{r}113 \cdot 2 \\
104 \cdot 4 \\
99 \cdot 6 \\
109 \cdot 0 \\
100 \cdot 1\end{array}$ & $\begin{array}{l}99 \cdot 5 \\
99 \cdot 7 \\
99 \cdot 7 \\
99 \cdot 4 \\
98 \cdot 8\end{array}$ & $\begin{array}{l}2 \cdot 10 \\
0 \cdot 24 \\
0 \cdot 02 \\
0 \cdot 55 \\
1 \cdot 02\end{array}$ & $\begin{array}{l}2 \\
2 \\
2 \\
2 \\
2\end{array}$ & $\begin{array}{l}0.30-0.50 \\
0.80-0.90 \\
0.98-0.99 \\
0.70-0.80 \\
0.50-0.70\end{array}$ \\
\hline
\end{tabular}

The greatest divergence between observation and expectation in Table IV occurs at 8 weeks of age and here the observed discrepancies or greater could have occurred by chance at least as often as three in ten trials.

Many suggestions have been made that establishing and maintaining breast feeding is more successfully carried out in the higher than in the lower social classes (Royal College of Obstetricians and Gynaecologists, 1948; Gordon, 1942; Douglas, 1950; Stewart and Westropp, 1953). Unfortunately no efficient index of social or economic status could be devised for the small number of mothers in the present survey, and it has not then been possible to take this factor into account. There is no reason to suppose, however, that the social status of the R.M.H. group differs in any marked degree from that of the Control group.

It will be appreciated that the method of selection of the members of the Control group resulted in including in that group children who were born in hospitals other than the Royal Maternity, in nursing homes, and in the mothers' own homes. Within the Control group a further possible source of variation can be examined, and although the proportion of hospital births in the Control group is small (30.2 per cent., compared with 58.6 per cent. births at home and 11.2 in nursing homes) it is possible that this small proportion does tend to make the Control group resemble the R.M.H. group rather more than a Control group selected entirely from non-hospital births would have done.

An examination was therefore made of three sub-groups of the Control group defined according to the actual place of confinement: hospital, nursing home, or home. The analysis, following the same pattern as that already used in the comparison between R.M.H. and Control groups, is presented in
Tables V and VI (opposite). The tests of significance are complicated by the small number of nursing-home births; consequently for each age two tests are shown, the first compares the feeding distributions of hospital births with those of all others and the second compares domiciliary births with all others.

At each age the distributions are very similar (Table V) and at no age is the discrepancy greater than could easily have occurred by chance. Although not significant by the adopted criterion, it does appear that infants who were delivered in their own homes received supplements at a rather earlier age than others, but greater numbers are required for a proper examination. When allowance is made for the factors of age of mother, parity, and type of ante-natal care as before, the observed and expected distributions show very good agreement and this is particularly marked in the first month of life (Table VI). The rather high ratios of observed to expected which appear in the nursing-home group are almost certainly attributable to the small numbers involved, and owing to the size of the sampling errors it is clear that the present data are unlikely to reveal a very reliable picture of breast feeding by mothers confined in nursing homes.

Within the limits of the factors examined in this paper, the difference in the subsequent feeding practice of mothers who have their babies in the Royal Maternity Hospital and those who are confined elsewhere is not very great. With the samples which we have used we have been unable to detect any statistically significant difference in the proportions breast-fed, breast-fed with supplements and fed by bottle and/or solids at any age up to 6 months between children born in the Royal Maternity Hospital and those born elsewhere. It is therefore reasonable to pool the two groups of 
TABLE V

PERCENTAGE DISTRIBUTION OF INFANTS BY METHODS OF FEEDING AT VARIOUS AGES IN SUB-GROUPS OF THE CONTROL GROUP CLASSIFIED BY PLACE OF CONFINEMENT

\begin{tabular}{|c|c|c|c|c|c|c|c|}
\hline \multirow{2}{*}{$\begin{array}{c}\text { Age } \\
\text { (wks) }\end{array}$} & \multirow{2}{*}{$\begin{array}{l}\text { Place of } \\
\text { Confinement }\end{array}$} & \multicolumn{3}{|c|}{$\begin{array}{l}\text { Method of } \\
\text { Feeding }\end{array}$} & \multicolumn{3}{|c|}{$\begin{array}{l}\text { Comparison between } \\
\text { Absolute distributions }\end{array}$} \\
\hline & & B & B + & NB & $x^{2}$ & $n$ & $P$ \\
\hline 0 & $\begin{array}{l}\text { Hospital } \\
\text { Home ... } \\
\text { Nursing Home }\end{array}$ & $\begin{array}{l}94 \cdot 9 \\
88 \cdot 1 \\
86 \cdot 2\end{array}$ & 二 & \begin{tabular}{r|}
$5 \cdot 1$ \\
11.9 \\
13.8 \\
\end{tabular} & $\begin{array}{l}3 \cdot 02 \\
1 \cdot 36\end{array}$ & 1 & $\begin{array}{l}0.05-0.10 \\
0.20-0.30\end{array}$ \\
\hline 1 & $\begin{array}{l}\text { Hospital } \\
\text { Home } . \\
\text { Nursing Home }\end{array}$ & $\begin{array}{l}84 \cdot 6 \\
72 \cdot 8 \\
79 \cdot 3\end{array}$ & \begin{tabular}{|r|}
7.7 \\
11.9 \\
6.9
\end{tabular} & $\begin{array}{r}7 \cdot 7 \\
15 \cdot 2 \\
13 \cdot 8\end{array}$ & $\begin{array}{l}3 \cdot 71 \\
3 \cdot 79\end{array}$ & $\begin{array}{l}2 \\
2\end{array}$ & $\begin{array}{l}0 \cdot 10=0 \cdot 20 \\
0 \cdot 10-0 \cdot 20\end{array}$ \\
\hline 2 & $\begin{array}{l}\text { Hospital } \\
\text { Home ... } \\
\text { Nursing Home }\end{array}$ & $\begin{array}{l}67 \cdot 9 \\
58 \cdot 3 \\
75 \cdot 9\end{array}$ & \begin{tabular}{|l|}
$14 \cdot 1$ \\
$17 \cdot 2$ \\
$10 \cdot 3$
\end{tabular} & \begin{tabular}{|l|}
$17 \cdot 9$ \\
$24 \cdot 5$ \\
$13 \cdot 8$
\end{tabular} & $\begin{array}{l}1 \cdot 14 \\
3 \cdot 81\end{array}$ & 2 & $\begin{array}{l}0.50-0.70 \\
0.10-0.20\end{array}$ \\
\hline 3 & $\begin{array}{l}\text { Hospital } \\
\text { Home .. } \\
\text { Nursing Home }\end{array}$ & $\begin{array}{l}55 \cdot 1 \\
55 \cdot 0 \\
72 \cdot 4\end{array}$ & $\begin{array}{r}9.0 \\
14.6 \\
6.9\end{array}$ & $\begin{array}{l}35 \cdot 9 \\
30 \cdot 5 \\
20 \cdot 7\end{array}$ & $\begin{array}{l}1 \cdot 79 \\
2 \cdot 27\end{array}$ & 2 & $\begin{array}{l}0.30-0.50 \\
0 \cdot 30-0.50\end{array}$ \\
\hline 4 & $\begin{array}{l}\text { Hospital } \\
\text { Home .. } \\
\text { Nursing Home }\end{array}$ & $\begin{array}{l}47 \cdot 4 \\
47 \cdot 0 \\
51 \cdot 7\end{array}$ & \begin{tabular}{|l|}
$12 \cdot 8$ \\
$17 \cdot 2$ \\
$13 \cdot 8$
\end{tabular} & \begin{tabular}{|l|}
$39 \cdot 7$ \\
$35 \cdot 8$ \\
$34 \cdot 5$
\end{tabular} & $\left|\begin{array}{l}0 \cdot 78 \\
0 \cdot 83\end{array}\right|$ & $\begin{array}{l}2 \\
2\end{array}$ & $\begin{array}{l}0.50-0.70 \\
0.50-0.70\end{array}$ \\
\hline 8 & $\begin{array}{l}\text { Hospital } \\
\text { Home } . . \\
\text { Nursing Home }\end{array}$ & $\begin{array}{l}35 \cdot 9 \\
26 \cdot 5 \\
34 \cdot 5\end{array}$ & \begin{tabular}{|l|}
$14 \cdot 1$ \\
$19 \cdot 9$ \\
$13 \cdot 8$
\end{tabular} & $\begin{array}{l}50 \cdot 0 \\
53 \cdot 6 \\
51 \cdot 7\end{array}$ & $\begin{array}{l}2 \cdot 02 \\
3 \cdot 04\end{array}$ & $\begin{array}{l}2 \\
2\end{array}$ & $\begin{array}{l}0 \cdot 30-0 \cdot 50 \\
0 \cdot 20-0 \cdot 30\end{array}$ \\
\hline 12 & $\begin{array}{l}\text { Hospital } \\
\text { Home } . . \\
\text { Nursing Home }\end{array}$ & $\begin{array}{l}28 \cdot 2 \\
17 \cdot 2 \\
27 \cdot 6\end{array}$ & $\begin{array}{l}12 \cdot 8 \\
18 \cdot 5 \\
10 \cdot 3\end{array}$ & $\begin{array}{l}59 \cdot 0 \\
64 \cdot 2 \\
62 \cdot 1\end{array}$ & $\begin{array}{l}3 \cdot 05 \\
5 \cdot 18\end{array}$ & $\begin{array}{l}2 \\
2\end{array}$ & $\begin{array}{l}0 \cdot 20=0 \cdot 30 \\
0 \cdot 05-0 \cdot 10\end{array}$ \\
\hline 16 & $\begin{array}{l}\text { Hospital } \\
\text { Home } . . \\
\text { Nursing Home }\end{array}$ & $\begin{array}{l}21 \cdot 8 \\
14 \cdot 6 \\
24 \cdot 1\end{array}$ & $\left|\begin{array}{r}11 \cdot 5 \\
12 \cdot 6 \\
3 \cdot 4\end{array}\right|$ & \begin{tabular}{|l|}
$66 \cdot 7$ \\
$72 \cdot 8$ \\
$72 \cdot 4$
\end{tabular} & $\begin{array}{l}1 \cdot 28 \\
2 \cdot 94\end{array}$ & $\begin{array}{l}2 \\
2\end{array}$ & $\begin{array}{l}0 \cdot 50-0 \cdot 70 \\
0 \cdot 20-0 \cdot 30\end{array}$ \\
\hline 20 & $\begin{array}{l}\text { Hospital } \\
\text { Home .. } \\
\text { Nursing Home }\end{array}$ & $\begin{array}{r}15 \cdot 4 \\
9 \cdot 9 \\
17 \cdot 2\end{array}$ & \begin{tabular}{|l|}
$12 \cdot 8$ \\
$10 \cdot 6$ \\
$10 \cdot 3$
\end{tabular} & $\begin{array}{l}71 \cdot 8 \\
79 \cdot 5 \\
72 \cdot 4\end{array}$ & $\begin{array}{l}1 \cdot 35 \\
2 \cdot 39\end{array}$ & $\begin{array}{l}2 \\
2\end{array}$ & $\begin{array}{l}0.50-0.70 \\
0.30-0.50\end{array}$ \\
\hline 24 & $\begin{array}{l}\text { Hospital } \\
\text { Home } . . \\
\text { Nursing Home }\end{array}$ & $\begin{array}{r}7 \cdot 7 \\
5 \cdot 3 \\
13 \cdot 8\end{array}$ & $\begin{array}{r}15.4 \\
9.9 \\
13.8\end{array}$ & $\begin{array}{l}76 \cdot 9 \\
84 \cdot 8 \\
72 \cdot 4\end{array}$ & $\begin{array}{l}1 \cdot 37 \\
3 \cdot 42\end{array}$ & 2 & $\begin{array}{l}0.50-0.70 \\
0.10-0.20\end{array}$ \\
\hline
\end{tabular}

At each age the percentages are based on the following numbers of infants:

$$
\begin{array}{lrr}
\text { Hospital. . } & . . & 78 \\
\text { Home .. } & . . & 151 \\
\text { Nursing Home .. } & 29
\end{array}
$$

For each age the first $\chi^{2}$ value refers to a test between "Hospital" and "Home and Nursing Home Combined", and the second $\chi^{2}$ value to a test between "Home" and "Hospital and Nursing Home Combined".

\section{TABLE VII}

ACTUAL AND PERCENTAGE DISTRIBUTION OF INFANTS

\begin{tabular}{|c|c|c|c|c|c|c|c|c|c|}
\hline \multirow{2}{*}{$\begin{array}{c}\text { Age } \\
\text { (wks) }\end{array}$} & \multicolumn{3}{|c|}{ Number } & \multicolumn{3}{|c|}{$\begin{array}{l}\text { Percentage of Total } \\
(500) \text { at Each Age }\end{array}$} & \multicolumn{3}{|c|}{$\begin{array}{l}\text { Standard Error of } \\
\text { Percentage }\end{array}$} \\
\hline & B & $\overline{\mathbf{B}+}$ & $\overline{\mathrm{NB}}$ & B & B+ & NB & B & $\mathbf{B +}$ & NB \\
\hline $\begin{array}{l}0 \\
1 \\
2 \\
3 \\
4\end{array}$ & $\begin{array}{l}452 \\
382 \\
322 \\
291 \\
249\end{array}$ & $\begin{array}{l}\overline{57} \\
80 \\
71 \\
77\end{array}$ & $\begin{array}{r}48 \\
61 \\
98 \\
138 \\
174\end{array}$ & $\begin{array}{l}90 \cdot 4 \\
76 \cdot 4 \\
64 \cdot 4 \\
58 \cdot 2 \\
49 \cdot 8\end{array}$ & $\begin{array}{l}1 \overline{11.4} \\
16.0 \\
14 \cdot 2 \\
15.4\end{array}$ & $\begin{array}{r}9.6 \\
12.2 \\
19.6 \\
27.6 \\
34.8\end{array}$ & $\begin{array}{l}1 \cdot 32 \\
1 \cdot 90 \\
2 \cdot 14 \\
2 \cdot 21 \\
2 \cdot 24\end{array}$ & $\begin{array}{l}\overline{1.42} \\
1.66 \\
1.56 \\
1.62\end{array}$ & $\begin{array}{l}1 \cdot 32 \\
1.46 \\
1 \cdot 78 \\
2 \cdot 00 \\
2 \cdot 13\end{array}$ \\
\hline $\begin{array}{r}8 \\
12 \\
16 \\
20 \\
24\end{array}$ & $\begin{array}{r}166 \\
116 \\
88 \\
61 \\
28\end{array}$ & $\begin{array}{l}71 \\
68 \\
55 \\
52 \\
66\end{array}$ & $\begin{array}{l}263 \\
316 \\
357 \\
387 \\
406\end{array}$ & $\begin{array}{r}33 \cdot 2 \\
23 \cdot 2 \\
17.6 \\
12 \cdot 2 \\
5.6\end{array}$ & $\begin{array}{l}14 \cdot 2 \\
13 \cdot 6 \\
11 \cdot 0 \\
10 \cdot 4 \\
13 \cdot 2\end{array}$ & $\begin{array}{l}52 \cdot 6 \\
63 \cdot 2 \\
71 \cdot 4 \\
77 \cdot 4 \\
81 \cdot 2\end{array}$ & $\begin{array}{l}2.11 \\
1.89 \\
1.71 \\
1.46 \\
1.03\end{array}$ & $\begin{array}{l}1.56 \\
1.53 \\
1.40 \\
1.37 \\
1.52\end{array}$ & $\begin{array}{l}2 \cdot 23 \\
2 \cdot 16 \\
2 \cdot 02 \\
1 \cdot 87 \\
1 \cdot 75\end{array}$ \\
\hline
\end{tabular}
IN R.M.H. AND CONTROL GROUPS COMBINED BY METHOD OF FEEDING AT VARIOUS AGES

\section{TABLE VI}

DISTRIBUTION OF INFANTS IN "PLACE OF CONFINEMENT" SUB-GROUPS OF THE CONTROL GROUP BY METHOD OF FEEDING COMPARED WITH DISTRIBUTIONS EXPECTED ON THE HYPOTHESIS THAT NO DIFFERENCE EXISTS BETWEEN THE THREE SUB-GROUPS AFTER ALLOWANCE FOR DIFFERENCES IN AGE OF MOTHER, PARITY, AND

\begin{tabular}{|c|c|c|c|c|c|c|c|}
\hline \multirow{2}{*}{$\begin{array}{c}\text { Age } \\
\text { (wks) }\end{array}$} & \multirow{2}{*}{$\begin{array}{c}\text { Place of } \\
\text { Confinement }\end{array}$} & \multicolumn{3}{|c|}{$\begin{array}{l}\text { Method of } \\
\text { Feeding }\end{array}$} & \multicolumn{3}{|c|}{$\begin{array}{l}\text { Comparison between } \\
\text { Absolute Distributions }\end{array}$} \\
\hline & & B & B+ & NB & $x^{2}$ & $n$ & $P$ \\
\hline 0 & $\begin{array}{l}\text { Hospital } \\
\text { Home } \\
\text { Nursing } \\
\text { Home }\end{array}$ & $\begin{array}{r}102 \cdot 2 \\
100 \cdot 0 \\
93 \cdot 9\end{array}$ & $\begin{array}{l}- \\
-\end{array}$ & $\begin{array}{r}71 \cdot 7 \\
99 \cdot 7 \\
168 \cdot 8\end{array}$ & $\begin{array}{l}0.62 \\
0.0004\end{array}$ & $\begin{array}{l}1 \\
1\end{array}$ & $\begin{array}{l}0.30-0.50 \\
0.98-0.99\end{array}$ \\
\hline 1 & $\begin{array}{c}\text { Hospital } \\
\text { Home } \\
\text { Nursing } \\
\text { Home }\end{array}$ & $\begin{array}{r}103 \cdot 3 \\
98 \cdot 1 \\
100 \cdot 3\end{array}$ & $\begin{array}{r}96 \cdot 8 \\
104 \cdot 9 \\
75 \cdot 8\end{array}$ & $\begin{array}{r}75 \cdot 9 \\
106 \cdot 1 \\
116 \cdot 6\end{array}$ & $\begin{array}{l}0.71 \\
0.45\end{array}$ & $\begin{array}{l}2 \\
2\end{array}$ & $\begin{array}{l}0.70-0.80 \\
0.70-0.80\end{array}$ \\
\hline 2 & $\begin{array}{l}\text { Hospital } \\
\text { Home } \\
\begin{array}{c}\text { Nursing } \\
\text { Home }\end{array}\end{array}$ & $\begin{array}{r}100 \cdot 9 \\
96 \cdot 0 \\
117 \cdot 0\end{array}$ & $\begin{array}{r}100 \cdot 0 \\
105 \cdot 0 \\
70 \cdot 9\end{array}$ & $\begin{array}{r}96 \cdot 7 \\
107 \cdot 1 \\
67 \cdot 0\end{array}$ & $\begin{array}{l}0.03 \\
0.96\end{array}$ & $\begin{array}{l}2 \\
2\end{array}$ & $\begin{array}{l}0.98-0.99 \\
0.50-0.70\end{array}$ \\
\hline 3 & $\begin{array}{l}\text { Hospital } \\
\text { Home } \\
\text { Nursing } \\
\text { Home }\end{array}$ & $\begin{array}{r}93 \cdot 1 \\
99 \cdot 0 \\
123 \cdot 5\end{array}$ & $\begin{array}{r}100 \cdot 4 \\
104 \cdot 2 \\
68 \cdot 7\end{array}$ & $\begin{array}{r}112.7 \\
99.9 \\
66.0\end{array}$ & $\begin{array}{l}0.90 \\
0.14\end{array}$ & 2 & $\begin{array}{l}0.50-0.70 \\
0.90-0.95\end{array}$ \\
\hline 4 & $\begin{array}{l}\text { Hospital } \\
\text { Home } \\
\text { Nursing } \\
\text { Home }\end{array}$ & $\begin{array}{r}100 \cdot 5 \\
97 \cdot 9 \\
109 \cdot 4\end{array}$ & $\begin{array}{r}96 \cdot 8 \\
100 \cdot 9 \\
102 \cdot 6\end{array}$ & \begin{tabular}{r|}
$100 \cdot 4$ \\
$102 \cdot 4$ \\
87.8
\end{tabular} & $\begin{array}{l}0.02 \\
0.15\end{array}$ & 2 & $\begin{array}{l}0.99-1.00 \\
0.90-0.95\end{array}$ \\
\hline 8 & $\begin{array}{l}\text { Hospital } \\
\text { Home } \\
\text { Nursing } \\
\text { Home }\end{array}$ & $\begin{array}{r}119 \cdot 2 \\
87 \cdot 4 \\
114 \cdot 4\end{array}$ & $\begin{array}{r}84 \cdot 5 \\
108 \cdot 4 \\
93 \cdot 0\end{array}$ & $\begin{array}{r}94 \cdot 0 \\
104 \cdot 4 \\
93 \cdot 9\end{array}$ & $\begin{array}{l}1.90 \\
2.62\end{array}$ & $\begin{array}{l}2 \\
2\end{array}$ & $\begin{array}{l}0.30-0.50 \\
0.20-0.30\end{array}$ \\
\hline 12 & $\begin{array}{l}\text { Hospital } \\
\text { Home } \\
\text { Nursing } \\
\text { Home }\end{array}$ & $\begin{array}{r}118 \cdot 6 \\
84 \cdot 3 \\
121 \cdot 4\end{array}$ & \begin{tabular}{r|}
$100 \cdot 2$ \\
$102 \cdot 3$ \\
$82 \cdot 4$
\end{tabular} & $\begin{array}{r}93 \cdot 0 \\
104 \cdot 6 \\
95 \cdot 8\end{array}$ & $\begin{array}{l}1 \cdot 31 \\
2 \cdot 21\end{array}$ & $\begin{array}{l}2 \\
2\end{array}$ & $\begin{array}{l}0.50-0.70 \\
0.30-0.50\end{array}$ \\
\hline 16 & $\begin{array}{l}\text { Hospital } \\
\text { Home } \\
\text { Nursing } \\
\text { Home }\end{array}$ & $\begin{array}{r}118 \cdot 7 \\
82 \cdot 8 \\
136 \cdot 7\end{array}$ & \begin{tabular}{r|}
$105 \cdot 4$ \\
$109 \cdot 4$ \\
$32 \cdot 4$
\end{tabular} & $\begin{array}{r}94 \cdot 3 \\
102 \cdot 7 \\
101 \cdot 1\end{array}$ & $\begin{array}{l}1 \cdot 02 \\
2 \cdot 43\end{array}$ & $\begin{array}{l}2 \\
2\end{array}$ & $\begin{array}{l}0.50-0.70 \\
0.20-0.30\end{array}$ \\
\hline 20 & $\begin{array}{l}\text { Hospital } \\
\text { Home } \\
\text { Nursing } \\
\text { Home }\end{array}$ & $\begin{array}{r}126 \cdot 3 \\
77 \cdot 7 \\
156 \cdot 3\end{array}$ & $\begin{array}{r}117.9 \\
93.1 \\
90.1\end{array}$ & $\begin{array}{r}93 \cdot 3 \\
104 \cdot 8 \\
93 \cdot 5\end{array}$ & $\begin{array}{l}1 \cdot 71 \\
3 \cdot 24\end{array}$ & $\begin{array}{l}2 \\
2\end{array}$ & $\begin{array}{l}0.30-0.50 \\
0.10-0.20\end{array}$ \\
\hline 24 & $\begin{array}{l}\text { Hospital } \\
\text { Home } \\
\text { Nursing } \\
\text { Home }\end{array}$ & $\begin{array}{r}104 \cdot 2 \\
75 \cdot 8 \\
236 \cdot 7\end{array}$ & $\begin{array}{r}120 \cdot 4 \\
87 \cdot 6 \\
102 \cdot 3\end{array}$ & $\begin{array}{r}96.4 \\
103.8 \\
89.7\end{array}$ & $\begin{array}{l}0 \cdot 74 \\
2 \cdot 51\end{array}$ & $\begin{array}{l}2 \\
2\end{array}$ & $\begin{array}{l}0.50-0.70 \\
0.20-0.30\end{array}$ \\
\hline
\end{tabular}
TYPE OF ANTE-NATAL CARE

(Observed numbers shown as percentages of expected numbers)

The numbers of infants in the sub-groups are as follows:

$$
\begin{array}{llr}
\text { Hospital. . } & \ldots & 78 \\
\text { Home } & \ldots & 151 \\
\text { Nursing Home } & . . & 29
\end{array}
$$

For each age the first $\chi^{2}$ value refers to a test between "Hospital" and "Home and Nursing Home Combined", and the second $\chi^{2}$ value to a test between "Home" and "Hospital and Nursing Home Combined".

births to obtain one distribution which gives a reasonable description of baby-feeding methods for the city as a whole (Table VII).

From the first week of life to the 24th the proportion of children in the group "breast-fed with supplements" varies very little and appears to amount to between 10 and 16 per cent. of all live 
births. The decline in the proportions solely breast-fed as age advances is evident from Table VII. The salient features of these trends would appear to be:

(a) About one in every ten children born alive is never breast-fed.

(b) At the end of the first week of life about threequarters of infants are fed solely on the breast while about one-eighth have breast milk and supplements and one-eighth have only artificial foods.

(c) At the end of the first month of life only 50 per cent. of children are solely breast-fed, and just over one-third have ceased to have breast milk.

(d) At the end of 2 months these proportions are reversed: one-third are solely breast-fed and one-half have ceased to be fed from the breast.

(e) At the end of 6 months about 80 per cent. of all infants are weaned and only 5 per cent. are existing entirely on breast milk.

\section{COMPARISON WITH OTHER STUdIES}

Although a large literature exists in which estimates of proportions of breast-fed children at various ages are featured, many difficulties arise in comparing these estimates between different surveys. These difficulties arise because of a lack of uniformity in sources of data, methods of sampling, methods of reporting results, criteria of breast feeding, and allowance for relevant concomitant factors. Most surveys are limited to the retrospective consideration of case histories which have accumulated in the clinics of local authorities, or in hospitals, or in general practice; only a few surveys have reported the results of oberving a group of infants from birth. Most are based on the experience of "all available records", and rarely has recourse been made to complete groups of scientifically drawn samples. The ages at which estimates are given vary considerably and are sometimes only approximate. Most reports make no distinction between babies fed solely on the breast and those in whom breast feeding is supplemented by other diet. Allowance for factors likely to influence the results, where such allowance is made, usually limits the data to certain defined groups according to the types of birth concerned.

Nevertheless it seems desirable to have on record the Belfast results side by side with those of surveys which appear to be based on reasonable data, but in interpreting the inevitable comparisons considerable caution must be exercised because of the general lack of uniformity. In Table VIII (opposite), the results of the Belfast survey are shown with those of other surveys. The Table is limited to three approximate ages corresponding to the end of the first, third, and sixth months of life. The proportions of babies in the feeding groups corresponding to the present Group B (solely breast-fed) and the combined group B and B+ (breast-fed with or without supplements) are shown, where available, for these ages.

The details of the other work shown in Table VIII cannot be given here although some indication is given of the size of the survey and the type of data used, in the remarks column. It should be noted, however, that for Hofmeier and Noack (1942) their best results are tabulated; for Norval (1947) the average of her town and country results is given; for Kollmann (1940) the average of hospital and home births is shown. From the present investigation, and indeed from most reports, it is evident that there is little use in quoting the proportion of breast-fed children at the time of discharge from a hospital. Such estimates appear to bear little relationship to those obtaining at later ages, and it is a common finding that mothers will breast-feed their infants while in hospital, either because they know that it is expected or because they wish to avoid argument, although they have every intention of weaning their infants as soon as possible after discharge. Breastfeeding for a few days such as results from this, can be of little value to the child, and it may be a danger as the mother may wean the child to an unsuitable diet in the absence of medical advice. For these reasons we have made no reference to the very large series of results given by Bain (1948) for hospitals in the United States of America.

At the end of approximately one month, 50 per cent. of the infants in the present survey were breast-fed without supplementary diet; four other available estimates are shown in Table VIII, and in each case the corresponding proportion was 70 per cent. or over. At the same age, 65 per cent. of the Belfast infants in the present survey were receiving breast milk with or without supplements, and this proportion was exceeded by all but one of the other eight available estimates. The exception was the estimate of 63 per cent. made by Douglas (1950), which was based on the infants, surviving to their second year, whose mothers had been the subject of detailed study for National Survey of one week's births in England and Wales in 1946 (Royal College of Obstetricians and Gynaecologists, 1948). This series represents one of the few surveys based on a random sample of maternities, and although the breast-feeding data was obtained retrospectively and excludes those infants who died in their first year, it is probably among the most reliable of recent estimates.

At approximately the end of the third month, only 23 per cent. of the infants in the present series were breast-fed without supplements. Estimates 
TABLE VIII

PERCENTAGE DISTRIBUTION OF INFANTS BY METHOD OF FEEDING AT VARIOUS APPROXIMATE AGES

(Belfast results compared with other published results)

\begin{tabular}{|c|c|c|c|c|c|c|c|c|c|c|}
\hline \multirow{2}{*}{\multicolumn{2}{|c|}{ Reference }} & \multirow{2}{*}{\multicolumn{2}{|c|}{ Survey }} & \multicolumn{6}{|c|}{ Approximate age (mths) } & \multirow{3}{*}{ Remarks } \\
\hline & & & & \multicolumn{2}{|c|}{ One } & \multicolumn{2}{|c|}{ Three } & \multicolumn{2}{|c|}{ Six } & \\
\hline Author & Date & Place & Date & B & $\begin{array}{l}\mathbf{B} \& \\
\mathbf{B}+\end{array}$ & $\mathbf{B}$ & $\begin{array}{l}\text { B \& } \\
\text { B }+\end{array}$ & $\mathbf{B}$ & $\begin{array}{l}\text { B \& } \\
\mathbf{B}+\end{array}$ & \\
\hline Present survey & 1954 & Belfast & $1951-52$ & 50 & 65 & 23 & 37 & 6 & 19 & 500 infants followed from birth out of 558 \\
\hline $\begin{array}{l}\text { Deeny and } \\
\text { Murdock }\end{array}$ & 1944 & Belfast & $1941-42$ & & 75 & & 61 & & 43 & $\begin{array}{l}\text { Retrospective data on } 477 \text { infants available at } \\
\text { one year out of } 671 \text { randomly selected }\end{array}$ \\
\hline Douglas & 1950 & Gt. Britain & 1946 & & 63 & & 44 & & 31 & 4,669 infants followed from birth \\
\hline $\begin{array}{l}\text { Crosse and } \\
\text { Waller }\end{array}$ & 1943 & Birmingham & $1938-42$ & & & & 53 & & & M.O.H. returns of approximately 17,000 infants \\
\hline Dummer & 1949 & Hitchin & $1946-47$ & 70 & 75 & 50 & 53 & 13 & 31 & M.O.H. returns of 545 infants \\
\hline Gordon & 1942 & Ilford & 1938 & 73 & & & & 44 & & M.O.H. returns \\
\hline Hughes & 1942 & Newbiggen & 1940 & & & 32 & 42 & 19 & 28 & $\begin{array}{l}\text { M.O.H. returns of } 112 \text { infants out of } 117 \\
\text { attending clinic }\end{array}$ \\
\hline Robinson & 1939 & Liverpool & $1918-38$ & & & 50 & & 35 & & Retrospective data from clinic notes \\
\hline $\begin{array}{r}\text { Stewart and } \\
\text { Westropp }\end{array}$ & 1953 & Oxford & & 75 & & 61 & & & & $\begin{array}{l}574 \text { infants followed from birth-volunteers } \\
\text { in child survey }\end{array}$ \\
\hline $\begin{array}{l}\text { Stocks and } \\
\text { Stang }\end{array}$ & 1953 & $\begin{array}{l}\text { Area in } \\
\text { Lancs. }\end{array}$ & 1950 & & & 20 & & 14 & & 650 infants followed from birth out of 788 \\
\hline Wigley & 1946 & Barking & 1943 & & & 61 & & & & 1,182 infants \\
\hline Blessing & 1937 & Evanston & & & & 19 & 44 & 7 & 17 & 437 private patients, majority hospital births \\
\hline Kimball & 1951 & N.W. U.S.A. & & & & 37 & 46 & 20 & 23 & 409 private patients \\
\hline Norval & 1947 & $\begin{array}{l}\text { Rochester, } \\
\text { Minn. }\end{array}$ & - & & 70 & & 40 & & 21 & $\begin{array}{l}462 \text { private patients, mothers anxious to } \\
\text { breast-feed }\end{array}$ \\
\hline Gemsjäger & $1951-52$ & Hamburg & 1949 & & & & 62 & & 33 & M.O.H. returns \\
\hline $\begin{array}{l}\text { Hofmeier and } \\
\text { Noack }\end{array}$ & 1942 & Germany & & & & 35 & 73 & 9 & 30 & 1,000 consecutive clinic patients \\
\hline Kollman & 1940 & Nurnberg & 1937 & & 74 & & 16 & & & M.O.H. returns of 1,234 infants \\
\hline Krug & 1941 & $\begin{array}{l}\text { Cities of } \\
\text { Germany }\end{array}$ & 1937 & & 88 & 58 & 58 & & 25 & M.O.H. returns \\
\hline Pohlen & 1939 & Germany & 1936 & & 95 & & 75 & & 29 & M.O.H. returns for the whole country \\
\hline Ungar & 1949 & Germany & $1940-42$ & 83 & 95 & 39 & 80 & 5 & 40 & 858 infants attending clinic out of 884 \\
\hline Baumann & 1947 & $\begin{array}{l}\text { St. Gall, } \\
\text { Switzerland }\end{array}$ & & & & & 65 & & 17 & M.O.H. returns \\
\hline Merz & 1946 & Switzerland & & & & & 55 & & & Infant welfare records for whole country \\
\hline Rudberg & 1939 & Stockholm & $1922-37$ & & & 66 & 79 & 30 & 59 & $\begin{array}{l}\text { Retrospective data from } 2,013 \text { mothers } \\
\text { attending hospital out-patient department }\end{array}$ \\
\hline
\end{tabular}

from other sources vary between 19 and 66 per cent., and only two of the eleven available were lower than the present estimate. At the same age 37 per cent. of the Belfast infants in the present survey were receiving breast milk, with or without supplements. The seventeen other estimates in Table VIII range from 16 to 80 per cent., and only one is lower than that obtained from the present data. It is of interest to note, however, that several estimates (44 per cent., Douglas, 1950; 42 per cent., Hughes, 1942, from English sources; 44 per cent., Blessing, 1937; 46 per cent., Kimball, 1951 ; 40 per cent., Norval,
1947, from American sources) do not exceed the Belfast estimates by very much.

At the end of approximately 6 months only 6 per cent. of the present series of infants were fed on breast milk alone. Estimates from the other available sources ranged from 5 to 44 per cent., and again only one estimate of the available ten was lower than the present Belfast estimate. At the same age 19 per cent. of the present series were receiving breast milk with or without supplements. The fourteen other estimates range from 17 to 43 per cent. and only two were lower than that obtained in the present series. 
If the estimates of Table VIII can be taken at their face value, then it appears that the proportion of breast-fed children, with or without supplements, in Belfast during the first 6 months of life is consistently low compared with results obtained elsewhere. But it must be emphasized again that the comparison is very crude, because of the lack of uniformity between investigations, and because no account can be taken of expected sampling variations, or basic differences in the types of births considered. Moreover, it should be noted that several of the investigations refer to data collected during the war years which would tend to increase the proportions breast-fed if the findings of Baumann (1947) are of general application.

\section{SUMMARY}

(1) Children born in the Royal Maternity Hospital Belfast, during September, October, and November, 1951, who survived their first 6 months of life and whose mothers, during this time, were Belfast residents were observed for 6 months or until breast feeding stopped. All children were included except multiple births, seven whose mothers refused to co-operate, and one whose mother died. A random sample of other Belfast births in the same 3 months was similarly observed, and again multiple births were excluded together with one whose mother would not co-operate.

(2) Observation was achieved by monthly visits to the children's homes by health visitors at which particulars of the feeding of the children were ascertained.

(3) After allowing for the possible effects of age of mother, parity, type of ante-natal care, and place of confinement, no significant difference was found at any age up to 6 months between the proportion of children breast-fed with or without supplements in the group born in the Royal Maternity Hospital Belfast, and in those born elsewhere.
(4) Pooling the data of the two groups leads to a reasonable estimate of the incidence of breast feeding in Belfast (Table VII).

(5) Comparison with work done elsewhere gives the impression that breast feeding with or without supplements is less common at all ages up to 6 months than has been generally reported from other areas. Lack of uniformity in such surveys is such that not too much credence should be given to this comparison.

Our thanks are due to the Staff of the Royal Maternity Hospital, Belfast, for their co-operation in allowing us to draw upon their patients, and to Dr. H. A. Warnock and the Health Visitors of the Maternity and Child Welfare Department of Belfast Corporation, without whose wholehearted support this investigation could not have been carried out. We are also indebted to Mr. J. D. Merrett and Miss D. B. I. Wood of the Department of Social and Preventive Medicine, Queen's University of Belfast, for considerable help with the analysis of the data and preparation of the manuscript.

\section{REFERENCES}

Bain, K. (1948). Pediatrics, 2, 313.

Baumann, T. (1947). Schweiz. med. Wschr., 77, 839.

Blessing, R. (1937). J. Pediat., 10, 792.

Crosse, V. M., and Waller, H. K. (1943). Proc. roy. Soc. Med., 36, 382.

Cruickshank, R. (1945). Arch. Dis. Childh., 20, 145.

Deeny, J., and Murdock, E. T. (1944). Brit. med. J., 1, 146.

Douglas, J. W. B. (1950). J. Obstet. Gynaec. Brit. Emp., 57, 335.

Dummer, F. H. M. (1949). Brit. med. J., 2, 14.

Gairdner, P. (1945). Arch. Dis. Childh., 20, 22.

Gemsjäger (1952). Off. Gesundh Dienst. 13, 439.

Gordon, I. (1942). Arch. Dis. Childh., 17, 139.

Hofmeier, K., and Noack, M. (1942). Dtsch. med. Wschr., 68, 573.

Hughes, E. L. (1942). Brit. med. J., 2, 69.

Kimball, E. R. (1951). Quart. Bull. Nthwest. Unv. med. Sch., 25, 257.

Kollman, A. (1940). Öff. GesundhDienst., p. 386.

Krug, J. (1941). München med. Wschr., 88, 194.

Merz W R (1946) Schweiz med. Wschr., 76, 1177.

Norval, M. A. (1947). J. Pediat., 31, 415.

Pohlen, K. (1939). Off. GesundhDienst., 4B., 537.

Robinson, M. (1939). Arch. Dis. Childh., 14, 258.

Royal College of Obstetricians and Gynaecologists and Population Investigation Committee (1948). "Maternity in Great Britain". Oxford University Press, London.

Rudberg, S. (1939). Acta paediatr. (Stockh.), $24,92$.

Stevenson, S. S. (1947). J. Pediat., 31, 616.

Stewart, A., and Westropp, C. (1953). Brit. med. J., 2, 305.

Stocks, A. V., and Stang, F. (1953). Med. Offr., 89, 111 .

Ungar, R. (1949). Kinderärtztl. Praxis, 17, 285.

Westropp, C. (1953). Rrit. med. J., 1, 138.

Wigley, G. S. (1946). "Breast Feeding in Barking, 1943". Suppl. Annl Rep. M.O.H., Barking, Essex. 